\title{
Why and How Is Health a Human Right?
}

\section{Citation}

Sen, Amartya. 2008. Why and how is health a human right? The Lancet 372, no. 9655: 2010-2010.

\section{Published Version}

http://dx.doi.org/10.1016/S0140-6736(08)61784-5

\section{Permanent link}

http://nrs.harvard.edu/urn-3:HUL.InstRepos:3124128

\section{Terms of Use}

This article was downloaded from Harvard University's DASH repository, and is made available under the terms and conditions applicable to Other Posted Material, as set forth at http:// nrs.harvard.edu/urn-3:HUL.InstRepos:dash.current.terms-of-use\#LAA

\section{Share Your Story}

The Harvard community has made this article openly available.

Please share how this access benefits you. Submit a story.

\section{Accessibility}




\section{@ Why and how is health a human right?}

Published Online December 10, 2008 DOI:10.1016/S0140-

6736(08)61784-5

See Editorial page 2001

See Right to Health page 2047

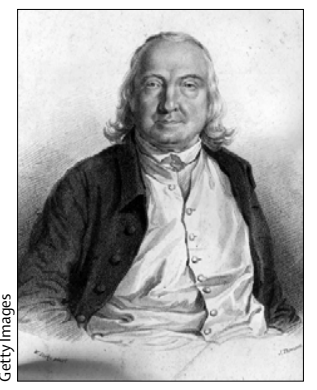

Jeremy Bentham (1748-1832) Engraving by JThomson, from a painting by W Derby; about 1825 .
In doing a special issue on the right to health, The Lancet is helping to draw attention to an extraordinarily important subject that does not get as much attention as it deserves. There are understandable reasons why the perspective of the right to health seems to many to be remote. First, there is what we might call the legal question: how can health be a right since there is no binding legislation demanding just that? Second, there is the feasibility question: how can the state of being in good health be a right, when there is no way of ensuring that everyone does have good health? Third, there is the policy question: why think of health, rather than health care, as a right, since health care is under the control of policy making, not the actual state of health of the people?

The legal question assumes that the idea of right has to be inescapably legal. Indeed, Jeremy Bentham described the 1789 French declaration of the rights of man (what rights every human being has) as "nonsense", since a right had to be, he argued, legislated and must be a "child of law". But there is a long tradition of thinking of rights in terms of social ethics: what a good society must have. Indeed, when the American Declaration of Independence invoked "certain inalienable rights" that everyone had, the idea of human rights served not as a "child of law" but more as a "parent of law" in guiding legislation. ${ }^{2}$ In seeing health as a human right, there is a call to action now to advance people's health in the same way that the 18th-century activists fought for freedom and liberty.

The feasibility question is based on a common confusion about what can or cannot be a right. If feasibility were a necessary condition for everyone to have any right, it would be nonsensical to say that everyone has the right to liberty, in view of the difficulty in ensuring the life and liberty of all against transgression. We cannot prevent the occurrence of murder somewhere or other every day. Nor, with the best of efforts, can we stop all mass killings. The acceptance of health as a right of all is a demand to take action to promote that goal, going beyond what is sometimes called the first-generation rights that involve personal liberties and political entitlements such as the right to vote (none of these rights are completely realisable).
The policy question points to the important fact that good health depends on health care, and health care is something that we can legislate about. But good health does not depend only on health care. It also depends on nutrition, lifestyle, education, women's empowerment, and the extent of inequality and unfreedom in a society. A human right can serve as a parent not only of law, but also of many other ways of advancing the cause of that right. Even the fulfilment of the first-generation rights (such as religious liberty, freedom from arbitrary arrest, the right not to be assaulted and killed) ${ }^{3}$ depends not only on legislation but also on public discussion, social monitoring, investigative reporting, and social work. ${ }^{4}$

The right to health has similarly broad demands that go well beyond legislating good health care (important as that is). There are political, social, economic, scientific, and cultural actions that we can take for advancing the cause of good health for all. .-10 $^{-10}$ Indeed, this special issue, which is aimed at knowledge and understanding of the parameters of the right to health, is itself a contribution to that splendid cause. In seeing health as a right, we acknowledge the need for a strong social commitment to good health. There are few things as important as that in the contemporary world.

\section{Amartya Sen}

Harvard University, Cambridge, MA 02138, USA

Igillen@fas.harvard.edu

I declare that I have no conflict of interest.

1 Bentham J. Anarchical fallacies; being an examination of the declaration of rights issued during the French revolution (1792). Republished in Bowring J, ed. The works of Jeremy Bentham, vol II. Edinburgh: William Tait, 1843: 523 .

2 Sen A. Elements of a theory of human rights. Philosophy Public Affairs 2004 32: 315-56.

3 UN. Universal Declaration of Human Rights. 1948. http://www.unhchr.ch/ udhr (accessed Dec 1, 2008).

4 Sen A. The limits of law. Cardozo Law Rev 2006; 27: 2913-27.

5 Sen A. Development as freedom. New York: Knopf, 1999.

6 Commission on Social Determinants of Health. Interim statement. 2007. http://whqlibdoc.who.int/publications/2007/interim_statement_eng.pdf (accessed Dec 1, 2008)

7 Marmot M. Tackling social factors to improve health Bull World Health Organ 2006; 84: 267-68.

8 Daniels N. Just health: meeting health needs fairly. New York: Cambridge University Press, 2007.

9 Ruger JP. Ethics of the social determinants of health. Lancet 2004; 364: 1092-97.

10 Ruger JP. Toward a theory of a right to health: capability and incompletely theorized agreements. Yale J Law Humanities 2006; 18: 273-326. 